\title{
Use of clonidine-naltrexone for rapid withdrawal in two patients dependent on intravenous morphine
}

\author{
Raveen Hanwella, Kosala Amaranayake, Madhubhashinee Dayabandara
}

\section{Summary}

There are no published reports of intravenous morphine abuse in Sri Lanka. We describe the use of rapid detoxification using clonidine and naltrexone in two patients dependent on intravenous morphine. There were minimal withdrawal effects and no serious adverse events during the withdrawal period. Both patients remain abstinent one month after completing the rapid withdrawal.

SL J Psychiatry 2011; 2 (2): 67-69

\section{Introduction}

Alcohol and tobacco are the commonest psychoactive substances used in Sri Lanka followed by cannabis and heroin (1-3). Heroin is the commonest opioid used in Sri Lanka and the main mode of administration is inhalation (3). It is estimated that only a small percentage, about $2 \%$, are intravenous users (3). Morphine is mainly used for medicinal purposes, but abuse has been reported from many countries. A survey of literature did not yield any published reports of intravenous morphine abuse in Sri Lanka.

In this case report we describe the use of rapid detoxification using clonidine and naltrexone in two patients dependent on intravenous morphine.

\section{Case Reports}

The first patient was a 28 year old male from Colombo who was employed as a lecturer. Introduced to heroin by a friend at the age of twenty two years, he initially used the inhalation method. He used nearly $250 \mathrm{mg}$ of heroin daily. Two years ago he decided to cease heroin use as it was a financial burden and had adverse effects on his career. He used morphine tablets to reduce the intensity of the withdrawal symptoms experienced after the discontinuation of heroin. The friend who introduced him to heroin informed him that intravenous use of morphine would relieve withdrawal symptoms faster than oral morphine and helped him prepare intravenous morphine by boiling oral tablets and water in a spoon held over a candle flame. Cotton wool or a cigarette butt was used as a filter to draw the liquid into a disposable syringe and it was injected into the cubital vein. He used three tablets at a time, twice a day. He had used IV morphine for 6 months. He also used alcohol, tobacco and cannabis.

The second patient was a 36 year old skilled manual worker who used heroin initially and changed over to morphine because of the scarcity of heroin. He too boiled morphine tablets in water and injected the liquid through the cubital vein. He had used IV morphine for 18 months.
Both patients were treated in the in-patient psychiatry unit of a teaching hospital. Prior to commencing rapid withdrawal, routine investigations including an electrocardiogram were performed. The treatment regime for rapid detoxification is given in table 1 . In addition to clonidine and naltrexone they were prescribed diazepam, paracetamol and diclofenac sodium. Blood pressure was measured before and at 30 minute intervals after each clonidine dose. In one patient, the blood pressure dropped below the protocol threshold of $90 / 60 \mathrm{~mm} \mathrm{Hg}$ and the next dose of clonidine was withheld. The patients were observed for withdrawal symptoms of morphine.

\begin{tabular}{|c|c|c|c|c|}
\hline & \multicolumn{2}{|c|}{ Clonidine } & \multicolumn{2}{|c|}{ Naltrexone } \\
\hline & $\begin{array}{l}\text { Time of } \\
\text { dose }\end{array}$ & Dose & $\begin{array}{l}\text { Time of } \\
\text { dose }\end{array}$ & Dose \\
\hline Day 1 & $\begin{array}{c}10 \mathrm{am} \\
2 \mathrm{pm} \\
6 \mathrm{pm} \\
10 \mathrm{pm}\end{array}$ & $\begin{array}{l}0.1 \mathrm{mg} \\
0.1 \mathrm{mg} \\
0.1 \mathrm{mg} \\
0.1 \mathrm{mg}\end{array}$ & $\begin{array}{c}10 \mathrm{am} \\
2 \mathrm{pm} \\
6 \mathrm{pm} \\
10 \mathrm{pm}\end{array}$ & $\begin{array}{l}- \\
- \\
-\end{array}$ \\
\hline Day 2 & $\begin{array}{c}10 \mathrm{am} \\
2 \mathrm{pm} \\
6 \mathrm{pm} \\
10 \mathrm{pm}\end{array}$ & $\begin{array}{l}0.2 \mathrm{mg} \\
0.2 \mathrm{mg} \\
0.2 \mathrm{mg} \\
0.2 \mathrm{mg}\end{array}$ & $\begin{array}{c}10 \mathrm{am} \\
2 \mathrm{pm} \\
6 \mathrm{pm} \\
10 \mathrm{pm}\end{array}$ & $\begin{array}{l}- \\
- \\
-\end{array}$ \\
\hline Day 3 & $\begin{array}{c}10 \mathrm{am} \\
2 \mathrm{pm} \\
6 \mathrm{pm} \\
10 \mathrm{pm}\end{array}$ & $\begin{array}{l}0.4 \mathrm{mg} \\
0.3 \mathrm{mg} \\
0.4 \mathrm{mg} \\
0.4 \mathrm{mg}\end{array}$ & $\begin{array}{c}10 \mathrm{am} \\
2 \mathrm{pm} \\
6 \mathrm{pm} \\
10 \mathrm{pm}\end{array}$ & $\begin{array}{l}25 \mathrm{mg} \\
12.5 \mathrm{mg} \\
12.5 \mathrm{mg} \\
25 \mathrm{mg}\end{array}$ \\
\hline Day 4 & $\begin{array}{c}10 \mathrm{am} \\
2 \mathrm{pm} \\
6 \mathrm{pm} \\
10 \mathrm{pm}\end{array}$ & $\begin{array}{l}0.4 \mathrm{mg} \\
0.3 \mathrm{mg} \\
0.3 \mathrm{mg} \\
0.4 \mathrm{mg}\end{array}$ & $\begin{array}{c}10 \mathrm{am} \\
2 \mathrm{pm} \\
6 \mathrm{pm} \\
10 \mathrm{pm}\end{array}$ & $\begin{array}{l}25 \mathrm{mg} \\
12.5 \mathrm{mg} \\
25 \mathrm{mg} \\
25 \mathrm{mg}\end{array}$ \\
\hline Day 5 & $\begin{array}{c}10 \mathrm{am} \\
2 \mathrm{pm} \\
6 \mathrm{pm} \\
10 \mathrm{pm}\end{array}$ & $\begin{array}{l}0.2 \mathrm{mg} \\
0.1 \mathrm{mg} \\
0.1 \mathrm{mg} \\
0.2 \mathrm{mg}\end{array}$ & $\begin{array}{c}10 \mathrm{am} \\
2 \mathrm{pm} \\
6 \mathrm{pm} \\
10 \mathrm{pm}\end{array}$ & $\begin{array}{l}25 \mathrm{mg} \\
25 \mathrm{mg} \\
25 \mathrm{mg} \\
25 \mathrm{mg}\end{array}$ \\
\hline Day 6 & $\begin{array}{c}10 \mathrm{am} \\
2 \mathrm{pm} \\
6 \mathrm{pm} \\
10 \mathrm{pm}\end{array}$ & $\begin{array}{l}0.1 \mathrm{mg} \\
0.1 \mathrm{mg} \\
0.1 \mathrm{mg} \\
0.1 \mathrm{mg}\end{array}$ & $\begin{array}{c}10 \mathrm{am} \\
2 \mathrm{pm} \\
6 \mathrm{pm} \\
10 \mathrm{pm}\end{array}$ & $\begin{array}{l}25 \mathrm{mg} \\
12.5 \mathrm{mg} \\
25 \mathrm{mg} \\
25 \mathrm{mg}\end{array}$ \\
\hline Day 7 & $\begin{array}{c}10 \mathrm{am} \\
2 \mathrm{pm} \\
6 \mathrm{pm} \\
10 \mathrm{pm}\end{array}$ & $\begin{array}{l}0.2 \mathrm{mg} \\
- \\
- \\
0.2 \mathrm{mg}\end{array}$ & $\begin{array}{c}10 \mathrm{am} \\
2 \mathrm{pm} \\
6 \mathrm{pm} \\
10 \mathrm{pm}\end{array}$ & $\begin{array}{l}25 \mathrm{mg} \\
- \\
- \\
25 \mathrm{mg}\end{array}$ \\
\hline
\end{tabular}


On day seven clonidine was discontinued and naltrexone which was started on day two was continued at a dose of $50 \mathrm{mg}$ per day. Both patients were discharged after one week in hospital and were reviewed as day patients. At one month review both patients maintained abstinence. One patient stopped naltrexone after a week due to the high cost.

\section{Discussion}

The primary treatment goals for opioid dependence may be either complete abstinence from all opioids or a substantial reduction in the use of opioids and illegal drugs (4). Methadone maintenance treatment is rarely used in Sri Lanka because IV opioid use is very rare. In intravenous drug users methadone maintenance helps reduce transmission of Human Immunodeficiency Virus (HIV) and Hepatitis B and other complications related to IV drug use.

Opioid detoxification with either methadone or buprenorphine is effective in treating withdrawal symptoms (5). Methadone a synthetic opiate is a $\mu$ opiate agonist. However it is known to be cardiotoxic and also causes respiratory depression. Concomitant use of heroin and methadone can lead to overdose. Buprenorphine is a partial $\mu$ opiate agonist which is given sublingually and is effective in the treatment of opioid withdrawal (6). Buprenorphine is used either alone or in combination with the opioid antagonist naloxone. The latter combination is used to prevent the abuse of buprenorphine. The American Psychiatric Association guidelines recommend buprenorphine in patients with mild to moderate opioid dependence (4).

Clonidine and lofexidine are alpha 2 adrenergic agonists which inhibit the release of noradrenaline and thereby reduce the autonomic symptoms of opioid withdrawal (7). A Cochrane Review has concluded that clonidine and lofexidine are more effective than placebo in treating opioid withdrawal but less effective than methadone and buprenorphine (8). However clonidine has several advantages compared to opioids. It does not maintain opioid dependence features, has no risk of abuse and patients can be started on naltrexone sooner. In patients using short acting opioids, like heroin, clonidine is usually given for four to six days (4). Close monitoring of blood pressure is necessary because of the risk of hypotension and dosages should be reduced if blood pressures fall below 90/60. Clonidine is associated with adverse effects such as hypotension, dizziness, dry mouth and lack of energy. Lofexidine does not reduce blood pressure to the same extent as clonidine. There is no significant difference in efficacy between lofexidine and clonidine (6). The lower incidence of hypotension makes lofexidine more suited for treatment in an outpatient setting than clonidine (6)

Naltrexone is a competitive antagonist at the mu and kappa opiate receptors in the brain. It blocks the effect of opioids and reduces conditioned craving (4). Naltrexone precipitates withdrawal in patients who are currently using opioids and patients should therefore be free of short acting opioids such as heroin for atleast 5 days before the initiation of naltrexone. The use of naltrexone in addition to behaviour treatment was found to be effective as maintenance treatment in reducing incarceration (9).

In rapid detoxification using combination of naltrexone and clonidine, the use of naltrexone precipitates withdrawal symptoms but these are reduced by pretreatment with clonidine (6). The naltrexone can then be continued in the maintenance phase. A Cochrane review of the use of opioid antagonists combined with alpha 2-adrenergic agonists suggests that withdrawal induced by opioid antagonists in combination with an adrenergic agonist is more intense than withdrawal managed with clonidine or lofexidine alone (10). In rapid detoxification a high level of monitoring is necessary for several hours following the administration of opioid antagonists because of the possibility of vomiting, diarrhoea and delirium. In some situations antagonist-induced withdrawal may be associated with significantly higher rates of completion of treatment, compared to withdrawal managed primarily with adrenergic agonists (10).Both our patients were free of severe withdrawal symptoms following the use of rapid detoxification. This was in contrast to the uncomfortable symptoms they had experienced previously when attempting withdrawal on their own. They also appeared to be coping with being abstinent better than after symptomatic detoxification.

Both patients remain abstinent one month after completing the rapid withdrawal. Rapid detoxification using a combination of clonidine and naltrexone could be a useful treatment in patients dependent on intravenous opioids. The main limitations for using this method are availability, cost and the need for close monitoring. Since clonidine is no longer used for the treatment of hypertension, its availability in Sri Lanka is limited. Naltrexone is not yet registered in Sri Lanka and needs to be obtained on a special licence. It is recommended that these two medications are made available in the hospitals or at least in specialised centres for the treatment of opiate withdrawal.

\section{Declaration of interest}

None

Raveen Hanwella, Senior Lecturer, Department of Psychological Medicine, Faculty of Medicine, Kynsey Road, Colombo 08, Sri Lanka

Kosala Amaranayake Registrar, University

Psychiatry Unit, NHSL,Colombo

Madhubhashinee Dayabandara, Lecturer in

Psychiatry, Department of Psychological Medicine

Faculty of Medicine, Colombo,Sri Lanka

\section{Corresponding author}

Raveen Hanwella, Department of Psychological

Medicine, Faculty of Medicine, Kynsey Road,

Colombo 08, Sri Lanka

E mail:raveenhanwella@yahoo.co.uk 


\section{References}

1. de Silva V, Samarasinghe D, Gunawardena N. Alcohol and tobacco use among males in two districts in Sri Lanka. Ceylon Med J. 2009;54(4):119-24. CrossRef

2. de Silva V, Samarasinghe D, Hanwella R. Association between concurrent alcohol and tobacco use and poverty. Drug Alcohol Rev. 2011;30(1):69-73. CrossRef

3. National Dangerous Drugs Control Board. Handbook of Drug Abuse Information 2010. Colombo: National Dangerous Drugs Control Board Sri Lanka.

4. Kleber HD, Weiss RD, Anton RF, Jr., George TP, Greenfield SF, Kosten TR, et al. Treatment of patients with substance use disorders, second edition. American Psychiatric Association. Am J Psychiatry 2007 Apr;164 (4 Suppl):5-123. PMID:17569411

5. Van den Brink W, Haasen C. Evidenced-based treatment of opioid-dependent patients. Canadian journal of psychiatry Revue canadienne de psychiatrie. 2006 Sep;51(10):635-46.

6. Soyka M, Kranzler HR, van den Brink W, Krystal J, Moller HJ, Kasper S. The World Federation of Societies of Biological Psychiatry (WFSBP) guidelines for the biological treatment of substance use and related disorders. Part 2: Opioid dependence. The world journal of biological psychiatry : the official journal of the World Federation of Societies of Biological Psychiatry. 2011 Apr;12(3):160-87 PMID:21486104

7. Ockert DM, Volpicelli JR, Baier AR, Jr., Coons EE, Fingesten A. A nonopioid procedure for outpatient opioid detoxification. Journal of addiction medicine. 2011 Jun;5(2):110-4. CrossRef

8. Gowing L, Farrell M, Ali R, White JM.Alpha2-adrenergic agonists for the management of opioid withdrawal. Cochrane Database Syst Rev. 2009(2):CD002024.

9. Kirchmayer U, Davoli M, Verster AD, Amato L, Ferri A, Perucci CA. A systematic review on the efficacy of naltrexone maintenance treatment in opioid dependence. Addiction. 2002 Oct;97(10):1241-9. CrossRef

10. Gowing L, Ali R, White JM. Opioid antagonists with minimal sedation for opioid withdrawal. Cochrane Database Syst Rev. 2009(4):CD002021. 